\title{
Models of Man
}

\section{Philosophical Thoughts on Social Action MARTIN HOLLIS}

All social theorists and philosophers who seek to explain human action have a 'model of man', a metaphysical view of nature. Some make man a plastic creature of nature and nurture, some present him as the autonomous creator of his social world, some offer a compromise. Martin Hollis illustrates the conflicts and contrasts involved in these views and then develops a 'model of man' of his own.

Hard covers $£ 7.00$ net

Paperback $£ 2.50$ net

\section{Perception}

\section{A Representative Theory FRANK JACKSON}

What is the nature of, and what is the relationship between, external objects and our visual experience of them? In this book, Frank Jackson defends the answers provided by the traditional Representative theory of perception.

f6.50 net

\section{Aristotle's Concept of Dialectic} J. D. G. EVANS

Dr Evans offers here the first systematic account of Aristotle's theory. He explores how dialectic is related to other forms of enquiry, both scientific and philosophical, and demonstrates the central part which dialectic occupies in Aristotle's thought.

$£ 5.90$ net

Paperback Edition

\section{Hegel}

\section{CHARLES TAYLOR}

'This exposition of Hegel admirably combines detached criticism and intimacy with the subject.' Stuart Hampshire in The Observer

Paperback $\$ 4.95$ net

\section{CAMBRIDGE UNIVERSITY PRESS}


THE PIETY OF THINKING Essays by Martin Heidegger

Translation, Notes and Commentary by JAMES G. HART and JOHN C. $M A R A L D O$

In the debates ranging over the last fifty years there have been many proponents and critics of both the early and later Heidegger, but Heidegger himself has rarely had his say. This book presents the first English translations of relatively unknown but important texts in which Heidegger has discussed theology and religion.
Indiana
224 pages
1977
f8.25

\section{INTENTIONALITY A Study of Mental Acts}

RICHARD E. AQUILA

This book is a critical and analytical survey of the major attempts, in modern philosophy, to deal with the phenomenon of intentionality. By coordinating the semantical, metaphysical, and phenomenological approaches to the phenomenon, Dr Aquila undertakes to provide a basis for dialogue among philosophers of different persuasions.
Penn State
192 pages
1977
f10.15

\section{ALIENATION, PRAXIS, AND TECHNE IN THE THOUGHT OF KARL MARX}

By Kostas Axelos

Translated by RONALD BRUZINA

In this study of Marx and the role of technology in the modern world, Axelos interprets Marx from his own distinctive, thought-provoking, philosophical position. The book provides a meaningful interpretation of Marx and an introduction to Axelos's own philosophical thought.
Texas
464 pages
1977
$£ 9.40$

For further information and catalogues please write to:

AMERICAN UNIVERSITY PUBLISHERS GROUP LTD 70 Great Russell Street, London, WC1B 3BY

Tel : 014051822

\section{THE PHILOSOPHICAL QUARTERLY}

Contents of Volume 27, No. 109, October 1977

\section{ARTICLES}

PLATO ON NAMING

Gail Fine

AGAINST AN ORTHODOX INTERPRETATION OF HOBBES

KRIPKE ON IDENTITY AND NECESSITY

'WHY DO YOU THINK THAT . . .?' QUESTIONS

DISCUSSION

FREY ON INTERESTS AND ANIMAL RIGHTS

CRITICAL STUDY

JONATHAN BENNETT: LINGUISTIC BEHAVIOUR

BOOK REVIEWS

\section{BOOKS RECEIVED}

Edited in the University of St Andrews by Bernard Mayo with the assistance of Christopher Bryant, Anthony Ellis and Stephen Read

Published for the Scots Philosophical Club by the University of St. Andrews

David Bostock

Eugene Valberg

Tom Regan

Robin Cameron

Annual Subscriptions

Individuals $£ 4.00$ ( $\$ 10.50$ )

Institutions $£ 7.00(\$ 17.50)$

Single issues $£ 1.25$ or $\$ 3.00$ (Institutions $£ 2.00$ or $\$ 5.00$ )

for orders placed directly with the Journals Manager, Scottish Academic Press, Ltd., 33 Montgomery St., Edinburgh EH7 5JX, Scotland. 


\section{The Emergence of Norms}

\section{Edna Ullmann-Margalit}

This book shows how rational beings cannot avoid accepting certain kinds of rules, or norms, in order to deal with certain sorts of social situations, and it examines three paradigmatic types of interaction: prisoners' dilemma, co-ordination, and inequality situations. It includes interesting discussions of the generalization argument in moral philosophy and of Hobbesian social contracts. $£ 8$ Clarendon Library of Logic and Philosophy

Two Theories of Morality

\section{Stuart Hampshire}

Stuart Hampshire deals here with two radically different conceptions of morality: those of Aristotle and Spinoza. He discusses the relationship between ordinary moral institutions and moral theory, emphasizing that moral philosophy ought to lead to moral conversion in the individual. $\mathfrak{£ 3}$

\section{The Honest Mind}

The Thought and Work of Richard Price

\section{O. Thomas}

The author surveys Price's writings to find out whether his various activities were inspired by the same principles or ideals, and concludes that an understanding of his theology and moral philosophy is essential to the appreciation of his political ideals, particularly the defence of representative institutions and national autonomy. $£ 12.50$

\section{Divine Substance}

\section{G. C. Stead}

The concept of substance plays an important part in ancient philosophy no less than in the classical statements of Christian theology. This book covers the whole field in detail and gives a critical account of the development of the Christian doctrine of God. $\quad £ 12.50$

\section{Oxford University Press}




\section{WAITING FOR DEATH}

The Philosophical significance of Beckett's En Attendant Godot RAMONA CORMIER and JANIS L. PALLISTER

"This investigation of Beckett's view of the world in Waiting for Godot concentrates in detail on his somnambulistic characters and their foibles."-Library Journal
176 pages
forthcoming
$£ 6.00$

\section{KIERKEGAARD'S EXISTENTIAL ETHICS}

GEORGE J. STACK

In this absorbing and original work, the author has sought to delineate the central characteristics of Kierkegaard's ethics of subjectivity.
252 pages
1977
cloth $\mathfrak{£ 7 . 5 0}$
paper $£ 3.00$

\section{HEGEL'S PHENOMENOLOGY}

Part I: Analysis and Commentary

HOWARD P. KAINZ

This work meets the need, longstanding for a number of reasons, for an analysis and commentary on Hegel's Phenomenology, which is one of the most intricate works, formally and conceptually, in the entire history of philosophy.
208 pages
1976
cloth $£ 7.50$
paper $£ 2.65$

For further information please write to

UNIVERSITY OF ALABAMA PRESS

70 Great Russell Street, London, WC1B 3BY

Tel : 01-405 0182

\section{Oxford Journals}

\section{The British Journal of Aesthetics}

\section{Volume 17 No. 4 Autumn 1977}

\section{Contents}

\section{Aesthetic Relevance Harold Osborne}

Progress and Common Sense: Two Approaches to a Problem in Criticism Anthony Savile

Colours, Cognitivity and Aesthetics Joel Rudinow

Liars, Poets and Philosophers Richard Kamber

Nonsense W. Charlton

The Aristotelian Katharsis $\quad$ E. P. Papanoutsos

Love and Landscape Equation in Tamil Poetry K. Subrahmanian

Book Reviews

To place an order or obtain an inspection copy please write to:

Journals Manager, Oxford University Press, Press Road, Neasden, London NW10 0DD

\section{Oxford University Press}




\title{
Ethics, Value \& Reality
}

\section{Selected Philosophical Papers of Aurel Kolnai introduced by BERNARD WILLIAMS \& DAVID WIGGINS}

Though rooted in the phenomenology of Husserl (under whom he studied), Kolnai had a profound sympathy for such English philosophers as W. D. Ross, G. E. Moore and J. L. Austin, and he did much of his best work after arriving in England in the 1950s. It is from this period that ten papers have been chosen (two previously unpublished) as representative of his best work in ethics and in related areas of social philosophy and aesthetics.

£9.00 November

The Collected Works of Jeremy Bentham

\section{A Comment on the Commentaries \& A Fragment on Government}

\author{
edited by J. H. BURNS \& H. L. A. HART
}

A Fragment on Government was Bentham's first substantial publication, wherein he asserted the principle of utility; it was a by-product of a larger enterprise for a sustained critique of the view of law exhibited in William Blackstone's influential Commentaries on the Laws of Engfand. These two of Bentham's works, of great importance for an understanding of his thought and of the development of English legal theory, are here presented in a single volume in newly established texts with full annotation and indexing. Bentham's long autobiographical preface to the Fragment is included and for the first time printed in its entirety. f30.00 November

\section{Legal Obligation}

\section{J. C. SMITH}

Through the technique of ordinary language analysis Professor Smith probes some core issues of jurisprudence, presenting an original theory of law based on the concept of obligation. His study of the nature and meaning of obligation is also used to clarify such topics as the rule of law, equality before the law and fundamental rights.

f8.00

\section{James Mill on Philosophy and Education}

\section{W. H. BURSTON}

This study places Mill's Essay on Education in its historical context and examines the views expressed in this and in other writings, both private and published, in relation to Mill's practical experience and to his philosophical position as a whole.

£6.50

\section{The Athlone Press UNIVERSITY OF LONDON}




\section{RECENTIY PUBLISHED}

\section{HUSSERL}

Expositions and Appraisals FREDERICK ELLISTON and PETER MCCORMICK, editors 400 pages

$£ 14.25$

THE SYNOPTIC VISION Essays on the Philosophy of Wilfrid Sellars

C. F. DELANEY,

GARY GUTTING, MICHAEL J. LOUX and

W. DAVID SOLOMON

192 pages

$£ 11.25$

\section{PERSPECTIVES ON MORALITY}

Essays by William $\mathrm{K}$.

Frankena

KENNETH E. GOODPASTER, editor

252 pages

\section{FREE CHOICE}

A Self-Referential

Argument

JOSEPH BOYLE, GERMAIN GRISEZ and OLAF TOLLEFSEN

232 pages

$£ 12.00$

\section{UNDERSTANDING AND SOCIAL INQUIRY}

THOMAS A. McCARTHY and

FRED R. DALLMAYR

352 pages

For further information and catalogues please write to:

UNIVERSITY OF NOTRE DAME PRESS

70 Great Russell Street, London WC1B 3BY

Tel: 01-405 0182
Princeton

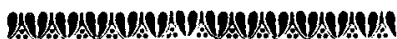

\section{Personal Destinies}

A Philosophy of Ethical Individualism

\section{David L. Norton}

Following in the footsteps of Plato and Aristotle, Kierkegaard and Nietzsche, Jung and Maslow, David Norton sets forth a distinctive vision of the individual's search for his place in the scheme of things.

Cloth, $£ 16.80$ • Paper, $£ 3.70$

\section{The Existentialist}

\section{Critique of Freud} The Crisis of Autonomy Gerald N. Izenberg Izenberg interprets the relationship of psychoanalysis and existentialism by examining the critiques of Freudian metapsychology in the work of existential philosophers and psychiatrists. $£ 12.30$

\section{The Philosophical}

Anarchism of William Godwin John P. Clark

This comprehensive study of Godwin's philosophy establishes the central importance of his ideas to modern social and political thought, correcting in the process certain widespread misinterpretations. $£ 12.30$

\section{Princeton} University Press

15A Epsom Road

Guildford, Surrey GU1 3TT 